\title{
Can quantum-chemical NMR chemical shifts be used as criterion for force-field development
}

\author{
Thomas E Exner ${ }^{1,2^{*}}$, Andrea Frank ${ }^{2}$, Heiko M Möller ${ }^{2}$, Martin Dračínský ${ }^{3}$ \\ From 9th German Conference on Chemoinformatics \\ Fulda, Germany. 10-12 November 2013
}

Fragment-based quantum chemical calculations based on our adjustable density matrix assembler (ADMA) are able to calculate NMR chemical shifts even for proteins and protein-protein complexes [1,2]. The agreement between the calculated and experimental chemical shifts in these calculations is, however, highly dependent on including conformational sampling and explicit solvent molecules. On the one hand, ensembles taken from classical MD simulations are suited for ${ }^{13} \mathrm{C}$ and ${ }^{1} \mathrm{H}$ chemical shift calculations if polar protons are neglected [3]. On the other hand, input structures from a Car-Parrinello MD resulted in landmark improvements over calculations based on classical MD especially for amide protons, which are predicted too high-field shifted based on the latter ensembles [4]. The better results are caused by the solute-solvents interactions forming shorter hydrogen bonds as well as by the internal degrees of freedom of the solute. With the obtained accuracy and the possibility of identifying the structural reasons for discrepancies between the experimental and calculated data, NMR chemical-shift calculations are now a perfect tool for e.g. the validation of new, improved force fields.
2. Frank A, Möller HM, Exner TE: Toward the Quantum Chemical Calculation of NMR Chemical Shifts of Proteins. 2. Level of Theory, Basis Set, and Solvents Model Dependence. J Chem Theory Comput 2012, 8:1480-1492.

3. Exner TE, Frank A, Onila I, Möller HM: Toward the Quantum Chemical Calculation of NMR Chemical Shifts of Proteins. 3. Conformational Sampling and Explicit Solvents Model. J Chem Theory Comput 2012, 8:4818-4827.

4. Dračínský M, Möller HM, Exner TE: Conformational Sampling by Ab Initio Molecular Dynamics Simulations Improves NMR Chemical Shift Predictions. J Chem Theory Comput 2013, 9:3806-3815, DOl:10.1021/ ct400282h.

\section{doi:10.1186/1758-2946-6-S1-O2}

Cite this article as: Exner et al:: Can quantum-chemical NMR chemical shifts be used as criterion for force-field development. Journal of Cheminformatics 2014 6(Suppl 1):O2.

\begin{abstract}
Authors' details
${ }^{1}$ Institute of Pharmacy, University of Tübingen, 72076 Tübingen, Germany. 2Department of Chemistry, University of Konstanz, 78457 Konstanz, Germany. ${ }^{3}$ Institute of Organic Chemistry and Biochemistry, Academy of Sciences, 166 10 Prague, Czech Republic

Published: 11 March 2014

References

1. Frank A, Onila I, Möller HM, Exner TE: Toward the Quantum Chemical Calculation of NMR Chemical Shifts of Proteins. Proteins 2011, 79:2189-2202.
\end{abstract}

\footnotetext{
* Correspondence: Thomas.Exner@uni-tuebingen.de

${ }^{1}$ Institute of Pharmacy, University of Tübingen, 72076 Tübingen, Germany
} Full list of author information is available at the end of the article

\section{Publish with ChemistryCentral and every scientist can read your work free of charge \\ "Open access provides opportunities to our colleagues in other parts of the globe, by allowing anyone to view the content free of charge." \\ W. Jeffery Hurst, The Hershey Company. \\ - available free of charge to the entire scientific community \\ - peer reviewed and published immediately upon acceptance \\ - cited in PubMed and archived on PubMed Central \\ - yours - you keep the copyright \\ Submit your manuscript here: \\ http://www.chemistrycentral.com/manuscript/

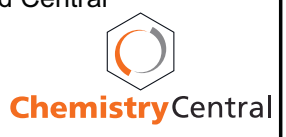

